\title{
METAL-DECORATED TEXTILES IN NON-DESTRUCTIVE ARCHAEOMETRIC STUDIES. EXAMPLES FROM POLAND
}

\begin{abstract}
Textiles from archaeological excavations are very interesting material for analyses, due to technological skills they demonstrate, as well as a diversity of raw materials. A collection of modern textiles with metal threads excavated at various archaeological funerary sites in Poland (e.g. churches in Gdańsk, Toruń, Gniew, Lublin, Płonkowo) were analysed by non-destructive analytical methods: microscopic observations and energy-dispersive X-ray fluorescence. With these techniques it was determined that the most popular metal threads were made of gilded silver. Others are made of pure silver and copper.
\end{abstract}

Keywords: textile, metal threads, archaeometry, ED-XRF, microscope, Poland, Polish funerary sites

\section{Introduction}

Archaeological textiles, despite partial preservation, for decades have been very interesting objects for research, especially for socio-cultural studies. Investigations of textiles and basketry provide information about technological skills as well as the economic level of ancient societies. For example, plant materials used by humans varied and were influenced by cultivated crops and their preparation and manufacture through a variety of conditions and treatments. Next, they often changed through their lifetime of wear and other work, sometimes not documented. They were deposited after use or for other reasons. Finally, often degraded or damaged textiles are analysed after excavation and conservation. An important factor that must be taken into account during textile investigation is that no two objects are the same. Conservators must learn to read the object, its inherent strengths and weaknesses, and the areas or materials most vulnerable to damage. We must recognise all signs of deterioration from colour changes, to weak structures and earlier repairs. The bad news is that deterioration of materials or structures can never be reversed. The same may also be said for earlier conservation treatments. Clearly, our treatments can interfere with future analyses of the object.

These changes are also identified in decorated textiles, which are binary or multi-part structures that were formed during textile production. The most popular decoration processes included weaving of coloured threads, dyeing,

* Institute of Archaeology, University of Wrocław; (D https:// orcid.org/0000-0003-3714-1889; beata.miazga@uwr.edu.pl stitching elements to fabric and embroidery. Metal threads were often used as structural parts. Due to many techniques of their production, Indictor and then Járó published a typology of such threads. ${ }^{1}$ There are plain metal threads with 'non-fibrous' metallic core. The other type are metal threads that were made as a wire or strips, which wrapped the fibre, e.g. silk, cotton or yarn. Both types of metal threads were produced from various metals (gold, silver, copper and their alloys) used as pure metals (silver, gold) or a thin coating of a noble metal over a non-precious metal base (single-sided or double-sided, i.e. silvered copper, silver-gilt). ${ }^{2}$ Strips used in textiles were also made from organic raw material, such as leather, animal membranes or paper. An excellent example of well preserved gilded organic base threads is on exhibition in the Metropolitan Museum of Art. The gold metal thread used for the background has a very interesting structure. A silk core was wrapped by thin, gilded organic raw materials (a membrane or a leather strip). The gold was of good quality, about 22-karat. ${ }^{3}$ Both the metal and organic bases could be coated by precious metals, often gold. Due to the macroscopic similarity of some metal threads, archaeometric studies are necessary for identifying the type of thread, especially as craftsmen used non-precious metals as a cheaper alternative for gold or silver.

${ }^{1}$ Indictor et al. 1989, 171-182; Járó et al. 2009, 68-76.

${ }^{2}$ Járó et al. 2000; Enguita et al. 2002, 328.

${ }^{3}$ http://www.metmuseum.org/exhibitions/listings/2013/invisible-visible. Featured Textile: fragment from the Dalmatic of San Valerius. Accessed 2.07.2018. 


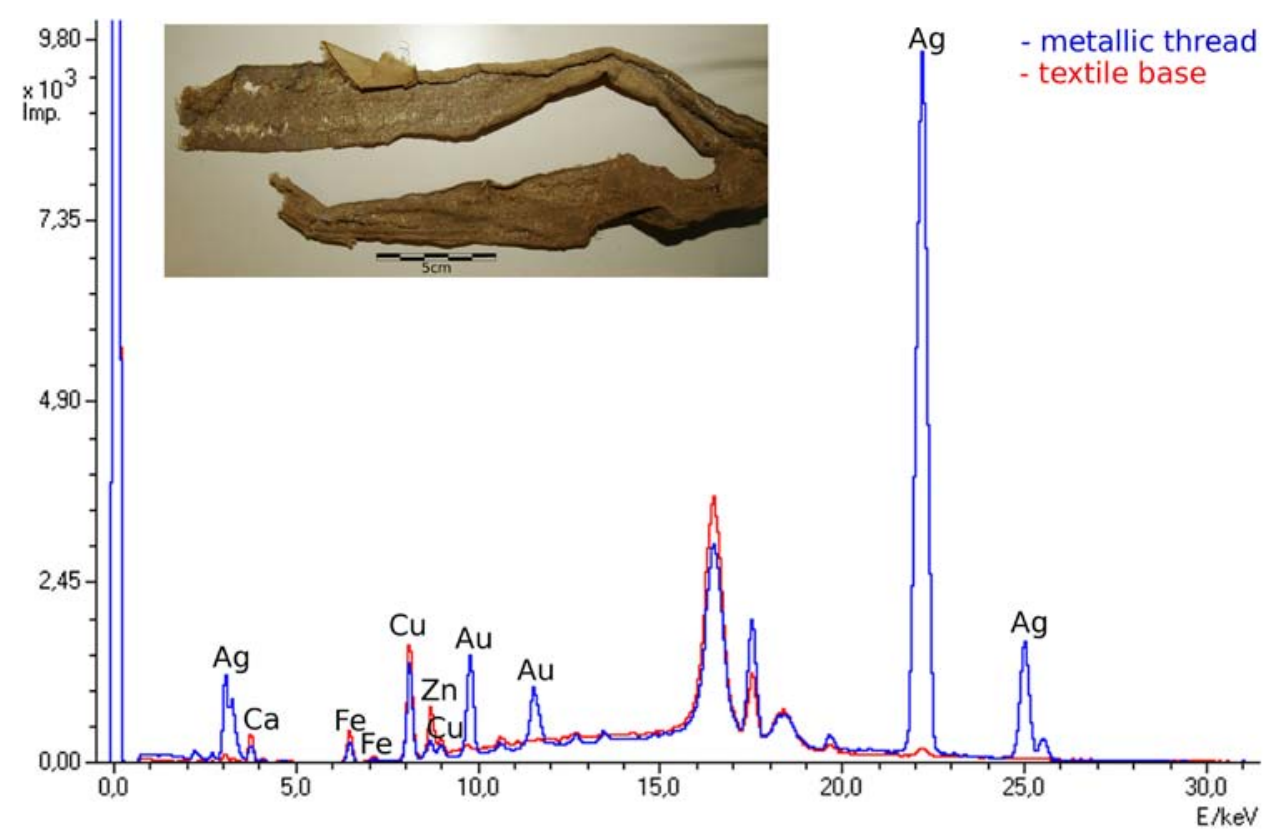

Fig. 1. Piaseczno, Tczew Dictrict. Artefact No. 10. ED-XRF spectra of metal threads. For all spectra in regions of 16.5-19.5 keV there are peaks connected with the spectrometer (raw material of X-ray lamp with molybdenum anode). By B. Miazga.

\section{Materials and methods}

For the archaeometric studies several archaeological textiles were obtained. Physicochemical investigations of textiles, although often carried out in Europe, ${ }^{4}$ are not very popular in Poland in contrast to microscopic studies of fibrous threads. ${ }^{5}$ The samples were provided by Małgorzata Grupa's research and are dated to early modern times (e.g. textiles from Płonkowo, Inowrocław District are dated to the $16^{\text {th }}$ $18^{\text {th }}$ century AD). ${ }^{6}$ The analysed textiles come from a funerary context: most of them were pieces of cloth or coffin decoration. Thirty artefacts were selected for investigation. The samples are in various state of preservation, but all were analysed after conservation work carried out by Małgorzata Grupa's team.

The analysis of metal threads was performed using energy-dispersive X-ray fluorescence (ED-XRF) with a Spectro Midex spectrometer. This instrument guarantees fast, universal, multi-elemental and non-destructive analysis. Moreover, it is equipped with a large chamber for samples, which enables the analysis of the entire artefact. Thanks to a video system for viewing samples and a $0.7 \mathrm{~mm}$ diameter of the measurement spot, it is also possible to choose small areas for analysis. The other advantage of Spectro Midex which is important for preserved items is a possibility of ignoring signals of light elements, which are present in conservations

\footnotetext{
${ }^{4}$ Nord and Tronner 2000, 275; Tronner et al. 2002, 110-112; Járó et al. 2009, 68-76.

${ }^{5}$ Grupa 2009, 158-173; Maik 2011; Grupa 2012; Grupa and Grupa 2013, 46-51; Dudziński et al. 2015, 84-94; Grupa et al. 2015a, 49-112.

${ }^{6}$ Grupa et al. 2015b; Nowosad et al. 2018, 65-78.
}

chemicals. The microscopic observation was carried out using two microscopes: a Nikon metallographic microscope with a magnification of 25-1000x and a Hirox 3D digital microscope with a magnification of 20-2000x. ${ }^{7}$ The selected devices are very important for a non-destructive analysis of the whole artefacts, without sampling the objects. It is very important for the items having a high historic value.

\section{Results}

The obtained results have been divided into two groups based on microscopic colour (goldish and silverish shine) and three based on the raw materials (alloys of gold, silver and copper). The most popular metal threads identified in the analysed textiles are made of silver-gold raw materials. ${ }^{8}$ ED-XRF analyses of 19 out of 30 artefacts revealed that the main component of the threads was silver, occurring in over $90 \%$ of these 19 items (Fig. 1). Other visible analytical signals belong to gold, iron and copper. Iron is a typical metallic contaminant and it is connected with the deposition of textiles. Copper is an element that accompanies silver in ore. Nonetheless, the small percentage of gold is very interesting, because it is responsible for the goldish colour of the threads. In the studied items, the share of gold was found to be $0.2 \%$ to $4 \%$. The gold concentration measured by ED-XRF with a high excitation energy beam could be falsely lower, due to a deeper penetration of threads by the X-ray beam. ${ }^{9}$

\footnotetext{
${ }^{7}$ Balta et al. 2015, 286.

${ }^{8}$ All the gilded silver threads are composed of flat strips of metal wound around a core of fibre.

${ }^{9}$ Nord and Tronner 2000, 275; Tronner et al. 2002, 110-112.
} 

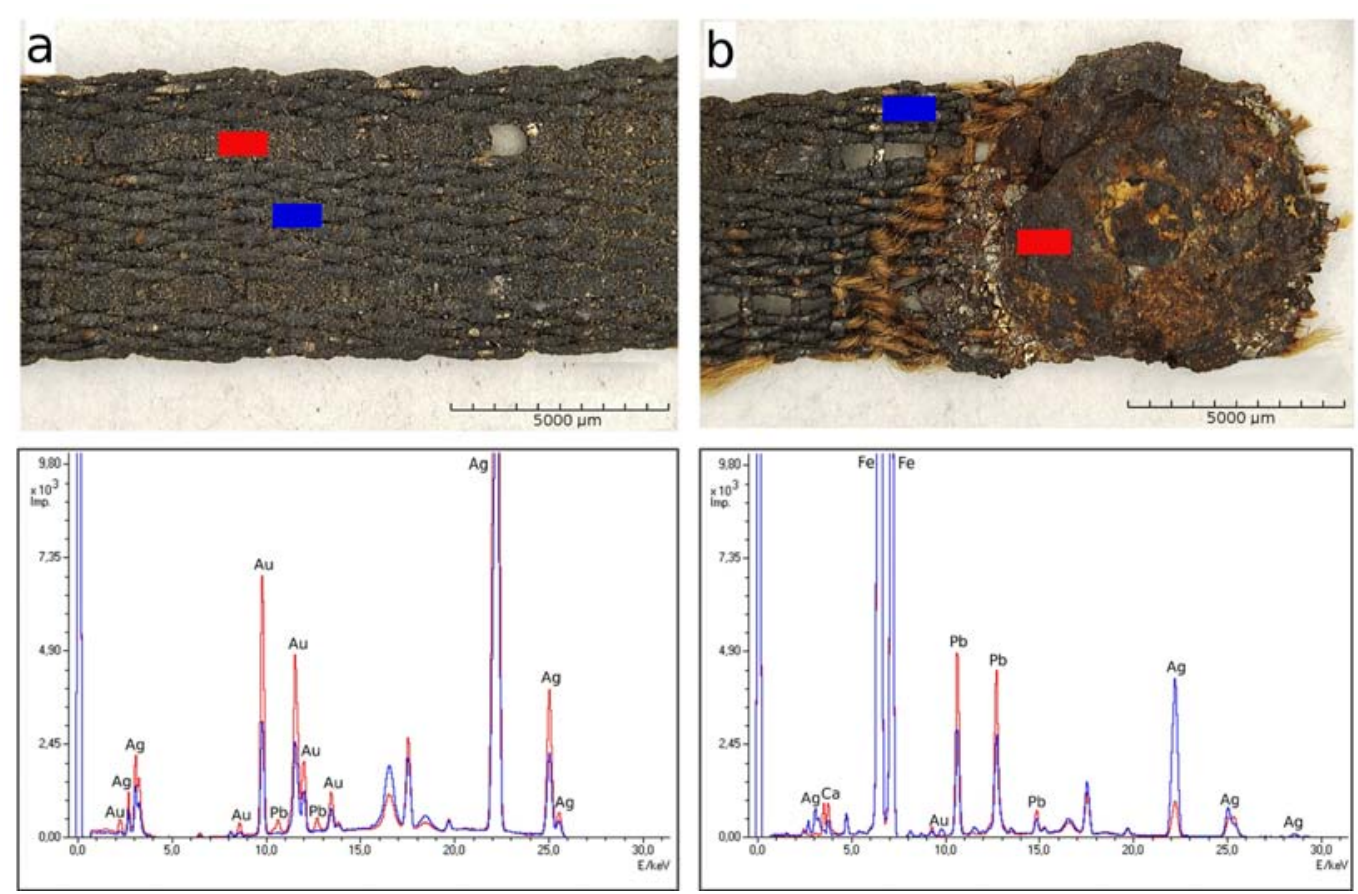

Fig. 2. Gniew, Tczew Dictrict. Artefact No. 33. Microphotograph and ED-XRF spectra of the ribbon, covered by a thick corrosion layer. By B. Miazga.

The gold percentage affects not only the colour of the thread, but also the state of preservation (gold is a noble metal and its oxidation is a very slow process), but this is not always the case. An excellent example of a deviation from this rule is the next presented artefact with golden colour strips, covered by thick layers of corrosion. Even in this state of preservation we were able to identify a golden colour in microscopic observation and silver and gold signals in the ED-XRF spectra (Fig. 2:a), as well as iron (Fig. 2:b). In this case, iron is probably a rivet in the ribbon, and is not a contamination, typical for items from archaeological excavations.

The microscopic observations were necessary not only for the items with corrosive deposits, but also for others. The examination of many textiles with the naked-eye is insufficient for the identification of the type of raw material and the colour of the thread. The analysed textiles prove that the golden shine of the treads is not always visible; some artefacts appear to be made of pure silver in a macroscopic view, but using a high magnification a golden colour can be recognised, even if it was sometimes covered by products of corrosion (Fig. 3). The observation of golden threads at a high magnification allowed us to determine a possible technology used in their preparation. The presence of a golden shine on both surfaces of the threads and its absence in the cross-section may prove that the threads were made by double-sized gilding of the silver base, probably wire, which had been flattened between two rollers (Fig. 4). ${ }^{10}$ The absence

\footnotetext{
${ }^{10}$ The term 'base' is connected with the metal which formed strips, e.g. for gilded silver threads it is silver.
}

of the golden colour on the side surface of the threads could be explained by the abrasion by neighbouring braids and the thinness of the gold layer. ${ }^{11}$ The destruction of gilding during use is highly possible. Gilded organic membranes were not identified, which is significant information for textile dating. Járó stated that from the $17^{\text {th }}$ century AD onwards metal threads with an organic base had been replaced by threads made of fibrous core covered by metals. ${ }^{12}$ All the identified gilded metal threads were made on a metallic base of silver.

Other gold-coloured threads are made of copper with a very small quantity of silver. The state of preservation of these threads is poorer than that of the gilded items. Frequently, the threads were covered by green layers, which is a product of copper corrosion. The oxidation of copper is remarkable and influences the ED-XRF results (Fig. 5). For a semi-quantitative analysis, the total metal content is significantly below $100 \%$ : often about $85 \%$, but sometimes only $20 \%$. The other difficulty is the contamination of the artefacts, which is visible as iron and calcium signals in the spectra. The identification of the original raw material (pure copper alloy of copper and silver, bronze or brass), used in the threads' production is sometimes impossible using non-destructive tools. Analysing the copper threads, we recognised how strong the influence of the metal was on the composition of the textile core. The XRF spectra for the textile core yielded very strong peaks of copper. Moreover, many microscopic photos show a green colour base, sometimes heavily

\footnotetext{
${ }^{11}$ Tronner et al. 2002, 109-112.

12 Járó et al. 2000, 95.
} 


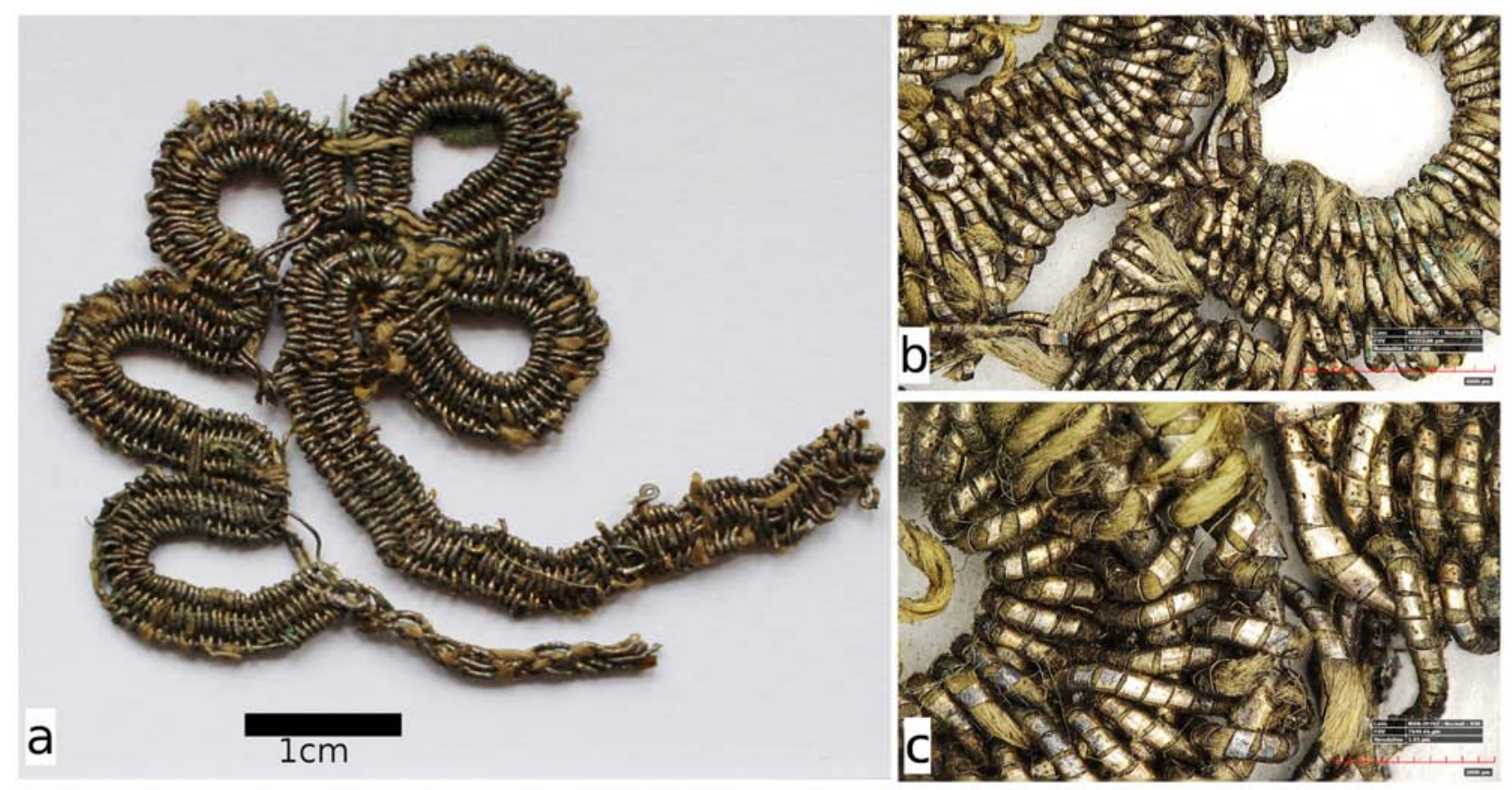

Fig. 3. Gniew, Tczew District. Artefact No. 7. Macroscopic (a) and microscopic (b-c) photos of a part of the textile. The golden shine is confirmed by observation at a 20-40x magnification. By B. Miazga.
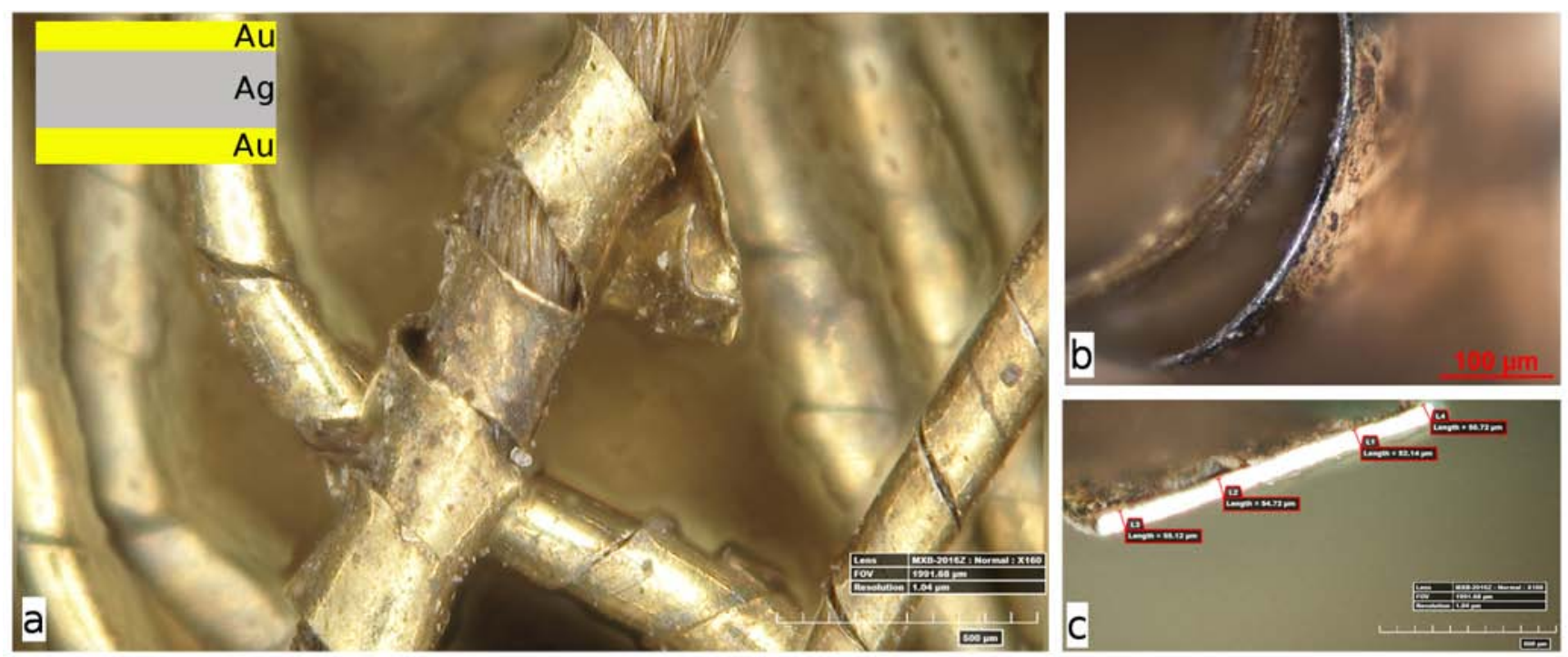

Fig. 4. Microscopic photos of selected textiles: a - Brzoza, Strzelce-Drezdenko District, button (Artefact No. 48); b - Torun, Torun District. Ribbon (Artefact No. 11); c- Gniew, Tczew District. Ribbon (Artefact No. 32). By B. Miazga.

mineralised, which may be an impediment in the investigation of fibres. Copper items, despite being the rarest type of threads, have an interesting diversity. Their size and shape are varied: e.g. ribbon was used as construction element of the textile or metal surrounding the textile core. The other elements are wires, made probably by drawing, because their diameter is constant for wires used for one and the same artefact. The recognised size of copper threads is variable. During our studies, it was realised that the tapes had a width from 200 to 600 micrometres and that the wire diameter was almost 90 micrometres. Based on microscopic observations, a possible technology used in the making of the copper threads was identified. Due to fact that the front and side surface of the threads look the same (they have a golden colour), it may be suggested that they were made as a homogeneous whole. At a high magnification grooves are visible that could be connected with rolling of the sheets or wires into a flat tape (ribbon).

The last group are silver threads, represented by $20 \%$ of all the analysed artefacts. The silver items are made of good quality raw material (about $98-99 \% \mathrm{Ag}$ ). The other elements are found at trace levels. This silver concentration allowed 

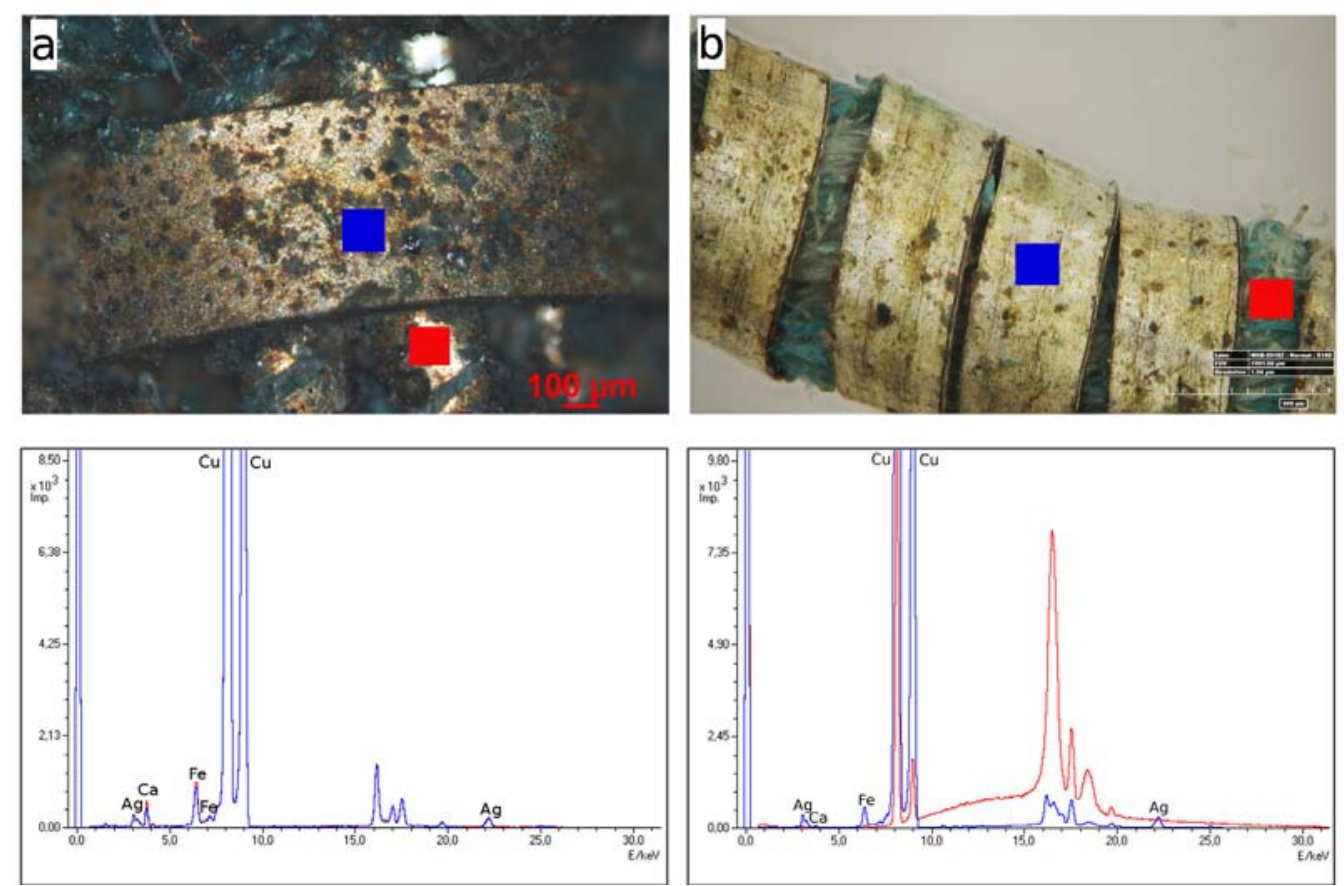

Fig. 5. ED-XRF spectra of copper threads: a - Płonkowo, Inowrocław District. Artefact No. 38; b - Biała Rawska, Rawa Mazowiecka District. Coffin decoration (No. 40). By B. Miazga.

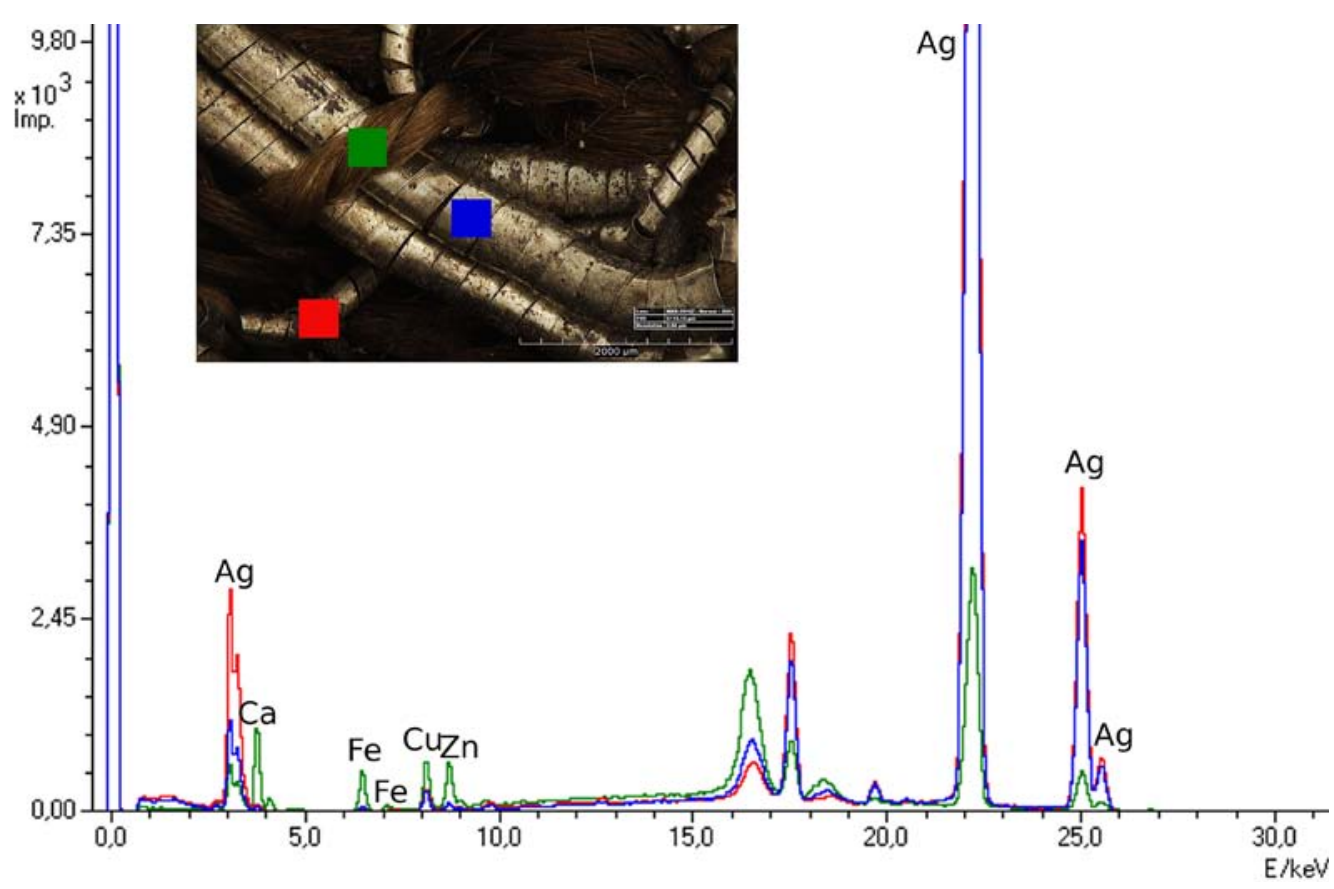

Fig. 6. ED-XRF spectra of silver threads (Artefact No. 21). By B. Miazga.

us to identify the raw material as 'pure silver'. ${ }^{13}$ We can see the ED-XRF spectra of the selected thread on Fig. 6. The strongest signals, visible on the photograph, belong to silver, the rest of identified metals have very weak peaks. In the textile core, the green line on Fig. 6, that is, the intensity of the signals, is different, because only the metals contaminated

\footnotetext{
${ }^{13}$ Balta et al. 2015, 287.
}

the organic textile core were measured by ED-XRF, e.g. calcium, iron, copper, zinc. The silver signals are weaker than in metal threads. Despite the high silver concentration in the raw material, these types of thread are preserved in various states of preservation. Some of them have an excellent metallic shine with the surface devoid of any oxidation product. Others are dark grey with many deposits of corrosion that are located on the entire surface of the metallic threads. Even in this case, raw material studies are still possible. 


\section{Conclusions}

The archaeometric investigations of archaeological textiles with non-destructive methods are a very useful tool for studies of such items. The results of such studies are numerous data, significant not only for further archaeological studies but also for conservation (its helps prepare a conservation program which is adequate to identified raw material and its state of preservation). The raw materials recognition as well as the technological analysis of the metal threads were impossible without the combination of microscopic observations and the chemical analysis. Even for the small thread fragments sometimes in a poor state of preservation or very corroded, the application of X-ray fluorescence spectrometry with a very concentrated radiation beam gave the interesting results in recognition of the most popular techniques and raw-materials used to threads production in modern times. All the analysed threads are made as metal strips wound around a fibrous core. The most abundant were gilded silver threads, over $60 \%$ of analysed items. Despite the great softness of the gold and sometimes its residual presence, the identification of the raw materials was possible. Moreover, the preliminary chronological estimation could also be done due to the double-sided gilding (see Fig. 4). The other raw materials, identified in the metals threads are copper and pure silver.

Taking into consideration the state of preservation of the artefacts (some were corroded, some cleaned and protected by various chemicals), the application of the Spectro Midex ED-XRF spectrometer was also a good decision, because this device can analyse artefacts without removing the conservation substances. It is possible because the spectrometer works in air and we can ignore the signals of light elements, like carbon and oxygen present in conservation chemicals, e.g. resins, or waxes.

\section{Bibliography}

Balta Z. I., Csedreki L., Furu E., Cretu I., Huszánk R., Lupu M., Török Z., Kertész Z., Sziksza Z. 2015. Ion Beam Analysis of Golden Threads from Romanian Medieval Textiles. "Nuclear Instruments and Methods in Physics Research B” 348, 285-290.

Dudziński T., Grupa M., Grupa D., Krajewska M., Majorek M., Nowak M., Nowak S., Przymorska-Sztuczka M., Wojciechowska A. 2015. Tajemnice szczuczyńskich krypt 3, Grajewo, Toruń.

Enguita O., Climent-Font A., Garcia G., Montero I., Fedi M. E., Chiari M. C., Lucarelli F. 2002. Characterization of Metal Threads Using Differential PIXE Analysis. "Nuclear Instruments and Methods in Physics Research B” 189, 328-333.

Grupa M. 2009. Tkaniny z krypty pótnocnej w Kwidzynie (Textiles from the Northern Crypt in Kwidzyn). In: M. Grupa, T. Kozłowski (eds.), Katedra w Kwidzynie - tajemnica krypt (Kwidzyn Cathedral - the Mystery of the Crypts). Kwidzyn, 149-174.

Grupa M. 2012. Wetniane tekstylia pospólstwa i plebsu gdańskiego (XIV-XVII w.) i ich konserwacja. Torun.

Grupa M., Grupa D. 2013. Wstążki, wstążeczki z krypt kościoła p.w. Imienia NMP w Szczuczynie. In: T. Dudziński, M. Grupa (eds.), Tajemnice szczuczyńskich krypt 1. Grajewo, 41-52.

Grupa M., Kozłowski T., Jankauskas R., Grupa D., Krajewska M., Krakowska S., Majorek M., Mosiejczyk J., Nowak M., Nowak S., Przymorska-Sztuczka M., Wojciechowska A. 2015a. Tajemnice krypty w kaplicy św. Anny (Secrets of the Crypt in St. Ann Chapel). Gniew.

Grupa M., Kozłowski T., Krajewska M., Grupa D., Janowska N., Jarzęcki K., Kurzawa D., Mucha N., Nowak M., Nowak S., Przymorska-Sztuczka M., Słomczewska M., Wojciechowska A., Majorek M. 2015b. Historia kościoła św. Oswalda w Ptonkowie (History of St. Oswald Church in Płonkowo) 1. Płonkowo.

Indictor N., Koestler R. J., Wypyski M., Wardwell A. E. 1989. Metal Threads Made of Proteinaceous Substrates Examined by Scanning Electron Microscopy: Energy Dispersive X-Ray Spectrometry. "Studies in Conservation" 34 (4), $171-182$.

Járó M. 2009. Metal Thread Variation and Materials: A Simple Method of Pre-treatment Identification for Historical Textiles. In: I. Eri (ed.), Conserving Textiles: Studies in Honour of Agnes Timar-Balazsi. ICCROM Conserving studies 7. Rome, 68-76.

Járó M., Gál T., Tóth A. 2000. The Characterization and Deterioration of Modern Metallic Threads. "Studies in Conservation" 45 (2), 95-105.

Maik J. 2011. Tkaniny. In: J. Piekalski, K. Wachowski (eds.), Ulice średniowiecznego Wrocławia. Wratislavia Antiqua. Studia z dziejów Wrocławia 11, Wrocław, 215-222, 262-263.

Nord A. G., Tronner K. 2000. A Note on the Analysis of Gilded Metal Embroidery Threads. "Studies in Conservation” 45 (4), 274-279.

Nowosad W., Grupa M., Grupa D. 2018. Relikty odzieży świeckiej (Secular Clothes Relics). In: M. Grupa, K. Jarzęcki, W. Nowosad (eds.), Historia kościoła św. Oswalda w Płonkowie (History of St. Oswald Church in Płonkowo) 2. Płonkowo, 65-78.

Tronner K., Nord A. G., Sjostedt J., Hydman H. 2002. Extremely Thin Gold Layers on Gilded Silver Threads. "Studies in Conservation" 47 (2), 109-116. 


\section{Internet sources}

http://www.metmuseum.org/exhibitions/listings/2013/invisible-visible. Featured Textile: Fragment from the Dalmatic of San Valerius, accessed 2.07.2018.

\section{Streszczenie}

\section{Tkaniny dekorowane metalem w nieinwazyjnych badaniach archeometrycznych. Przyklady z Polski}

Badania tkanin, zwłaszcza pochodzących ze stanowisk archeologicznych, stanowią ważny kierunek studiów naukowych zarówno ze względu na poznanie różnorodności surowcowej, jak i technologicznej. W artykule zaprezentowano wyniki analiz zbioru nowożytnych tkanin grobowych, pochodzących z badań przeprowadzonych m.in. w kościołach Gdańska, Torunia, Lublina oraz Płonkowa. Zastosowano nieniszczące metody analityczne: mikroskopię świetlną oraz energodyspersyjną spektroskopię fluorescencji rentgenowskiej. Obie te techniki są niezwykle często używane do badań zabytkowych przedmiotów. Podczas analiz archeometrycznych tekstyliów dowiedziono, że wśród badanych nici o metalowym oplocie dominują te wytworzone ze złoconego srebra, w mniejszości zaś są te wykonane z czystego srebra oraz miedzi. 